\title{
The Construction of Brand Denmark: A Case Study of the Reversed Causality in Nation Brand Valuation
}

\author{
Henrik Merkelsen and Rasmus Kjærgaard Rasmussen
}

\begin{abstract}
In this article we unpack the organizational effects of the valuation practices enacted by nation branding rankings in a contemporary case where the Danish government employed branding-inspired methods. Our main argument is that the use of nation branding was enabled by the Nation Brands Index via its efficient translation of fuzzy political goals into understandable numerical objectives. The Nation Brands Index becomes the driving force in a powerful bureaucratic translation of nation branding which in turn has several reordering effects at organizational level. We thus demonstrate how the Nation Brands Index permits bureaucratic expansion in central government administration as it continuously maintains and reconstructs problems solvable by the initiation of more nation branding initiatives and projects and hence more bureaucratic activity.
\end{abstract}

Key words: nation branding; measurement; reputation; risk; bureaucracy

In the aftermath of the so-called Cartoon Crisis ${ }^{1}$ the Danish government initiated an Action Plan for improving Denmark's nation brand. According to an image report published by nation brand expert

\footnotetext{
1 The Cartoon Crisis has been called "Denmark's worst international relations incident since the Second World War" (TimesOnline 2006). The crisis was caused by the publication of 12 drawings of the prophet Mohammed by the Danish newspaper Jyllands-Posten in the fall of 2005 as it caused massive discontent and protests from and around the Arab and Muslim world. It is estimated that a total of 150 people lost their lives as a consequence of the crisis (see also Rasmussen and Merkelsen 2014 for a comprehensive account).
}

Henrik Merkelsen, Department of Strategic Communication, Lund University, henrik.merkelsen@isk.lu.se

Rasmus Kjorgaard Rasmussen, Department of Communication, Business and information Technologies, Roskilde University, rasmuskr@ruc.dk

(C) 2015 Henrik Merkelsen and Rasmus Kjærgaard Rasmussen

LiU Electronic Press, DOI 10.3384/VS.2001-5992.1532181

http://valuationstudies.liu.se 


\section{Valuation Studies}

Simon Anholt immediately after the crisis, Denmark's brand had suffered severe damage in Middle-Eastern countries (Special Report 2006). In 2007 the Danish government's nation brand initiative was formally established and continued until 2012. From its inception the plan's explicit goal was improving value of the nation brand and the conceptualization of the plan was heavily inspired by the notion that a nation brand can and should be actively managed (Anholt 2007).

A vital component of this managerial approach to the country's reputation is the use of branding metrics by which the nation's brand value (or "brand equity", as much branding literature prefers) is constantly monitored, assessed and compared to other nations on a ranking scale. In the case of Denmark the metrics played a crucial role, as the overall objective of the branding initiative was to advance Denmark's position on the Anholt Nation Brands Index from fourteenth place to a place in the top ten. However, the government and the Task Force in charge of the Action Plan never fulfilled this objective and in 2013 after modification of the evaluation criteria the nation brand initiative was abandoned.

In this paper we approach nation branding indices and the practice of measuring countries' reputations as a specific valuation practice where political objectives are translated into quantifiable entities with significant rhetorical appeal (see Shore and Wright 1997). Within the neoliberal transparency regime associated with new public management (NPM) especially, rankings are a principal "mediating technology" for such political translations of valuation (see Hansen and Flyverbom 2015). Thus, our aim in this analysis is to unpack nation branding indices as valuation practices by looking at how they are institutionalized in political organizations in terms of policy formulation and organizing practices.

While valuation as a social phenomenon is complex and can be studied in many ways depending on whether the focus is production, diffusion, assessment or institutionalization (Lamont 2012) we address the specific challenges and implications of assessment. The new interdisciplinary literature on valuation emphasizes the two-fold nature of valuation as both prizing and appraising (Helgesson and Muniesa 2013). While common sense might suggest that some value must exist before it can be measured-i.e. that prizing in the sense of "holding precious" precedes appraising understood as "a rating activity" (cf. Dewey 1939, 5) - it is a central observation in our study that the practice concerning the rating of nation brands is an indispensable precondition for constructing the nation brand. In other words: the nation brand does not exist as such. It is a product of the very instruments that seek to measure it.

We illustrate this point by highlighting central findings from a comprehensive single case study of the Danish nation brand initiative (Rasmussen 2014; see also Rasmussen and Merkelsen 2012, 2014; for 
other accounts of this case see Ren and Gyimóthy 2013; Ren and Ooi 2013). The study is based on an ANT (Actor-Network Theory) methodology that included content analysis of policy documents and extensive ethnographic field study in the Danish government administration. Specifically the study draws on three sources of empirical material: 22 policy documents; 12 interviews with civil servants within central administration and external consultants; and ethnographic observation in the nation branding task force during eight months in 2009 (see Rasmussen 2014 for details). The present article however draws only on selected results of the study as it specifically underscores the effect that the Anholt Nation Brands Index had on policy formation and policy implementation.

In addressing the effects of this specific valuation practice we argue that even when accepting the functionalist premises that dominate nation branding practices, the metrics that allegedly measure some underlying values are problematic. This argument is underscored by debates in the branding literature concerning the level of aggregation in such measurements (see next section, Theoretical Perspectives). However, our empirical observations suggest that even though bureaucrats in the Danish central administration were aware of these problems, the nation brand measurements were successful in generating new organizing practices in central government administration. Thus, we demonstrate how the nation brands index affected policy formation; that it facilitated the expansion of bureaucracy by establishing new objects of control and coordination; and finally that it institutionalized a new organizational risk sensibility towards reputational fallout. In this respect the brand metrics had significant "re-ordering" effects (Helgesson and Muniesa 2013; Kjellberg et al. 2013) in terms of imposing a new value system in parts of the Danish government administration.

Departing from an ANT methodology and the notion of a flat ontology (e.g. Callon 1986; Latour 1986) we see branding metrics as actors that operate on the same level as subjects. Thus, we do not assume any hierarchy between objects and subjects. In this sense we contest a priori assumptions that metrics are results of underlying beliefs and social interests (cf. Vatin 2013). While we agree with the introductory editorial of this journal (Helgesson and Muniesa 2013) that values are socially constructed, in this paper we emphasize that the practice of valuation can itself construct new social realities (see also Hacking 1990; Porter 1995).

Conversely, we do not assume any preexisting hierarchy between theory and practices. Rather than seeing the empirical findings as expressions of deeper theoretical realities where academic analysis becomes epistemologically superior to practice, we understand both theory and practice as two equally important perspectives on the case. This assertion is visible in the structure of the article where we begin 


\section{Valuation Studies}

with a review of selected literature in order to give an account of the conceptual contexts of the Danish nation branding initiative. Thus, the literature section does not imply a specific theoretical perspective of our study.

We advance our arguments in four sections: After this introduction the second section introduces some theoretical perspectives on nation branding, aggregation and complexity in the functionalist literature that dominates nation branding practice. The third section analyses the practical institutionalization of brand metrics in the concrete policy formation process and illustrates the institutionalization of brand metrics in the policy implementation process surrounding the Danish government's use of nation branding. By pointing to how the Nation Brands Index as a measurement tool enacted its own object of measurement the final and fourth section concludes the article by emphasizing the argument concerning the reversed causality in nation brand valuation.

\section{Theoretical Perspectives on Nation Branding, Aggregation and Complexity}

Nation branding like the more general practice of place branding has received increasing academic attention over the past 20 years (Gertner 2011). While functionalist approaches dominate, often with practitioner gurus as the commonly referred to authorities, critical approaches have begun to voice important objections to the managerial ideology behind knowledge creation in the field (Kaneva 2011). However, functionalists have also pointed to serious conceptual weaknesses (Kavaratzis and Hatch 2013).

Both nation branding and place branding are heavily inspired by the concept of corporate branding (Kavaratzis 2009). This knowledge transfer from the corporate world to other domains has been labeled "the business analogy" (Collini 2012) and has also been critically approached within the literature on nation branding (Rasmussen and Merkelsen 2014). While managerial practices adopted from the corporate world have a strong appeal for policymakers (Dunleavy and Hood 1994) the models on which corporate practices are based often fail to take into account the complex environment that policymakers are facing. In much critical literature on nation branding, however, the critique is more profound and transcends problems concerning the technical adequacy of branding models. Rather, branding as a practice becomes synonymous with neoliberal ideologies of governance (Widler 2007; Stöber 2008; Kaneva 2012) where national culture and identity become the object of marketization (Jansen 2008; Kaneva and Popescu 2011).

The main arguments behind this line of criticism are that politics becomes depoliticized and that national identity and cultural differences become distorted by homogeneous managerial branding 
practices (Aronczyk 2008, 2009). A recurring point of reference in these studies is Naomi Klein's redefinition of the classic critique of capitalism into a general cultural critique of corporate brands and reputations (Klein 2000). In terms of valuation practices this criticism points to how fundamental cultural values are transformed by market logics of commodification where the notion of value is redefined as the capacity for generation of monetary surplus. In this the critique of the very ability to measure brand equity becomes paramount and the underlying metrics are perceived as harmful means that enable reproduction of capitalistic structures.

While critical approaches to nation branding as a cultural phenomenon see the measurement of brand equity as a symptom of an ideological hegemony that suppresses the underlying "real" values, the functional approaches are increasingly realizing the shortcoming of the metrics behind the measurements (Szondi 2010; Pamment 2014). However, contrary to critics of branding the functionalists see further inspiration from the corporate world as a possible solution to the theoretical underdevelopment. Thus, Kavaratzis and Hatch (2013) propose that a more nuanced understanding of the dynamics that shape place identities needs inspiration from literature on organizational identity. Their main objection is that the complexity of places is not sufficiently taken into account in the existing placebranding literature.

The challenges of complexity in corporate branding are well known (cf. Christensen et al. 2008). Like places, corporations often face the task of managing multiple stakeholders with diverse perceptions and conflicting interests. Thus, a major unresolved question in the literature on corporate branding is whether a company has "one reputation or many" (Helm 2007). The aggregation problems behind this question are illustrated by Wartick (2002) when comparing how different brands are valued differently depending on whether the brand is perceived from a specific stakeholder perspective or treated as the mean score of all stakeholder perspectives on an aggregate level. For instance, the corporate brand as the sum of mean scores of the parameters on which the brand is measured (e.g. value for money, financial performance, employer satisfaction, ecological effects, etc.) is often perceived differently by different stakeholder groups. For a stakeholder group like the consumer, value for money is likely to be more relevant than financial performance. In contrast, for the shareholders, financial performance is most relevant. Thus, the corporate brand as an aggregate based on mean scores of all stakeholder evaluations of all brand parameters is a very simplistic and imprecise representation of the company. In line with this functionalist critique the problem of complexity has been acknowledged as a serious challenge for nation branding (e.g. Blichfeldt 2005; Anholt 2006; Fan 


\section{Valuation Studies}

2006; Dinnie 2008), rendering the measurement thereof "fraught with difficulties" (Papadopoulos cited in Frost 2004, 1).

\section{Unpacking the Reordering Effects of the Nation Brands Index}

The Anholt Nation Brands Index came to play a principal role in commencing the Danish government's nation branding initiative. Nevertheless, policy documents show that central actors in government administration were concerned about the complexity issues surrounding nation branding as a practice. This suggests that the initiative from the outset had fundamental challenges in connecting means with ends. Apart from the difficulties in establishing a clear connection between the measurement methods and the object of measurement the Task Force also faced a problem with resolving an international policy controversy with a marketing strategy. However, in the analysis we show that these challenges were resolved by a series of translations, whereby the practice within the Task Force managed to abide by different-sometimes contradictory-logics while maintaining coherency in their practice. In fact, it is a main point in our analysis that the shortcomings of nation branding made it easy for bureaucrats in the central administration to fit nation branding into their existing bureaucratic practices.

\section{The First Translation: The Cartoon Crisis as a Reputational Problem}

The Nation Brands Index was first presented to the public in April 2007 when the Action Plan was passed by parliament. In this period it served as a catalyst that helped institutionalize the concept of nation branding at policy level-particularly in contemporary policy documents such as the Action Plan. The index thus became a vital part of the policy process that positioned nation branding as the solution to the reputational problem created by the cartoon crisis.

According to Latour (1999), any policy formation process can be seen as creation of an actor network. This creation will consist of a series of stages in which a problem is first constructed in a problematization scenario. This is followed by an interessement where an actor offers a solution; after which, actors seek to align their translations of a given solution by enrolling other actors in this, creating what Callon and Latour (1981) have called a macro-actor, i.e. a particularly powerful assemblage of interests.

The index was introduced to the Danish public in the aftermath of the cartoon crisis where Simon Anholt used the polling of Denmark as a proxy for measuring the impact of the crisis on Denmark's image (Anholt 2006). A press release from GMI (Global Market Institute) issued February 23, 2006 stating that Denmark was the most valuable nation brand measured per capita marked the beginning of this 
translation. The claim was substantiated by an extensive report with calculations of the brand value of a wide range of nations. Behind this report was the British nation branding consultant, Simon Anholt. National media picked up the story as it was newsworthy stuff on the backdrop of the cartoon crisis. Shortly afterwards GMI launched another press release after publishing a special report showing how severely the Danish nation brand was damaged in Middle-East countries as a consequence of the crisis.

Following Latour $(1986,1999)$ the index became a central actor in a two-step process, first, in the problem-construction stage where it played an important rhetorical role in the translation of the crisis from an international policy issue into a reputational problem. This translation was by no means plucked out of the blue. Only a few weeks previously, the Minister of Foreign Affairs framed the crisis as a reputational problem: "We have to safeguard our reputation as well as the persuasiveness and integrity of our culture" (Ministry of Foreign Affairs of Denmark 2006). This framing of the crisis was furthermore explicated by a former foreign minister stating that "Denmark's reputation has been seriously damaged" (Danish Broadcasting Corporation 2006). Second was in the solution stage where the translation of the crisis into a reputational problem was accompanied by nation branding as the proper solution. This happened when the rhetorical assemblage that connected the crisis to a reputational problem was successfully accepted by a broad range of political actors in Denmark who not only aligned their interpretation with Anholt's but also translated the index and nation branding as the solution to the original problem of the crisis.

The PR work effected by Simon Anholt and GMI thus played an important role in aligning the subsequent policy formulation process with the nation branding logic. From 2006 through 2007 a series of meetings took place between central government actors (i.e. the Ministry of Foreign Affairs, Danish Agency for Investment Attraction, Ministry of Economic and Business Affairs and the Danish Tourism Agency). These meetings resulted in a policy formulation that ultimately became the blueprint for the later Action Plan and in turn the national brand strategy to be implemented by the Task Force. Despite the skepticism concerning the adequacy of the nation branding metrics among some of these actors it is clear by looking at the final outcome that these are inscribed as a pivotal part of the international marketing policy.

Thus, the very first pages of the Action Plan evidence that this notion of surveying Denmark's nation brand is introduced as an integrated part of how to measure the plan's objectives. According to these, Denmark had to be "ranked amongst the top ten in 2015 of all the OECD countries ... in terms of awareness" (Danish Government 2007, 4). Apart from more general considerations concerning the 


\section{Valuation Studies}

importance of awareness, the plan says very little about how the fulfillment of the objectives will improve Denmark's international relations. However, the major strength of the index was that it assisted in translating the Danish government's somewhat fuzzy policy goals concerning a "global marketing" of Denmark into a measureable objective. The Action Plan emphasizes the link between different policy initiatives and their reputational outcome, albeit in very abstract formulations:

The Task Force's duty ... is to ensure the completion of successive surveys of the outside world's awareness of Denmark's strengths and competencies as well as of the results and progression of the initiatives. (Danish Government 2007, 55)

As such the index was a convenient tool for the Task Force that had been assigned to the almost impossible task of both coordinating and measuring the effects of highly different initiatives, of which many were already planned for in existing government budgets and thus adhered to existing political agendas. Measuring the coordinated effect of political initiatives ranging from education to export would not be easy; therefore the index came in handy for the Task Force.

\section{The Second Translation: Nation Branding as Bureaucratic Practice}

Operationalization of the index as an evaluation standard in the Action Plan made it a principal actor in terms of organizing and institutionalizing the Danish nation brand network. The first step was the process of policy formation. This phase of the nation branding initiative mostly consisted of formulating policy documents that served to establish the "rules of the game." In this phase the index helped the bureaucrats translate their existing bureaucratic practices into the nation branding logic. This is visible in policy documents that are dominated by branding terminology. In official documents from both the Ministry of Economic and Business Affairs and Ministry of Foreign Affairs, traditional foreign and trade policy challenges are increasingly framed as reputational issues and use a nation branding vocabulary (e.g. Danish Government 2006, 2007; Ministry of Foreign Affairs, 2009).

In terms of practice in the ministry, however, empirical observations showed the bureaucrats continued to follow a bureaucratic praxis (cf. Fenton and Langley 2011) in their daily routines. When asked about this discrepancy between policy and practice, the head of the Task Force explained that informally no one within the ministry believed that Denmark could achieve the objectives connected with the index. In fact, the bureaucrats in the Task Force considered the index highly ill-suited for measuring the effects of the plan's initiatives. This conviction had been prevalent since the plan was passed in 2007 and so had the widespread skepticism concerning the application of a 
nation branding framework. This is visible in the working documents that were written between the Globalization Strategy and the Action Plan. These documents echo concerns about complexity that had been voiced in the branding literature (see previous section, Theoretical Perspectives): "One cannot simply compare countries and nations with soda and soap. The differences are evident" (Danish Government $2006,2)$. As a consequence of this skepticism the bureaucrats in the task force had continuously lobbied for an alternative (i.e. nonbranding) method of evaluating the program within the parliamentary committee.

The reluctance towards the nation branding concept is partly explained by their professional identity: the members of the Task Force perceived themselves as bureaucrats and administrators before seeing themselves as nation branding practitioners. Thus, in the interviews, many respondents expressed ambivalence and skepticism towards the compulsory role as both bureaucrats and international marketeers given to them by the political leadership. Some of them entirely rejected the notion of working with nation branding, instead stressing that their job was to "implement and administer government policy" as one bureaucrat phrased it. And a few even dismissed the Branding Denmark Task Force as being a mere nominal construction decoupled from the "true" bureaucratic practice of ministry. These observations of the ambivalent encounter between bureaucracy and branding logics are described elsewhere as a clash of professional identities (see Rasmussen forthcoming).

That the bureaucratic logic proved resilient towards the nation branding logic is evident in how the Action Plan approached the implementation of the Danish nation branding policy. The most noticeable result was how it created new objects of bureaucratic control and coordination, i.e. new organizations. As a result of the Action Plan three new government organizations were established: the Foundation to the Marketing of Denmark; the Marketing Advisory Board; and the Branding Denmark Taskforce. Each organization was commissioned to coordinate and control the government's existing efforts on impression management and the marketing of Danish culture. This expansion of bureaucracy was followed by further expansions. As the central coordinating body from 2007 to 2012 the Task Force contributed to the establishment of a suite of publicprivate partnerships aiming at the marketing of specific Danish business sectors. As such the bureaucrats literally created the objects of their own bureaucratic control and coordination.

The actual practice within the Task Force was therefore characterized by two main translations. First, the cartoon crisis was translated into a reputational problem whereby nation branding was agreed upon as a viable solution. Then the nation branding process 


\section{Valuation Studies}

was translated into a bureaucratic modus operandi whereby existing bureaucratic structures simply expanded into a new domain.

\section{The Index Becomes a Continuous Generator of Problems and Solutions}

Despite the successful translation of nation branding into existing bureaucratic practices (and projects) made by the bureaucrats in the Action Plan, a series of problems began to surface when from 2007 onwards the nation branding policy was implemented. One of the main problems was the systemic challenge that the use of the index as an evaluation tool presented to central government administration, as the effects of ministries' work could not be measured on the index. Most of the marketing projects under the Action Plan did not follow a nation branding logic since most of them were existing projects within investment and tourism. It was unlikely that there would be any measurable nation branding effects from the many and somewhat disparate communication activities ranging from public diplomacy to the use of events such as the COP15 conference. The consequence of this mismatch was that the Task Force was unable to produce effects that would lead to the fulfillment of the overall objective: advancing Denmark's position on the Anholt Nation Brands Index to a place in the top ten.

This mismatch between means and ends, which had been successfully camouflaged at the level of policy formation, was epitomized by the yearly release of the Nation Brands Index which in consecutive reports revealed no change in Denmark's position. Thus, the country's position on the index was scored five times during the five years the Action Plan was in effect. But despite all efforts, from 2006 to 2011 Denmark's brand continually oscillated between the index's fourteenth and fifteenth places (see Table 1).

\begin{tabular}{|c|c|c|c|c|c|c|c|c|}
\hline \multicolumn{9}{|c|}{ Anholt-GfK Roper Nation Brands Index 2007-2011 } \\
\hline & 2007 & & 2008 & & 2009 & & 2010 & 2011 \\
\hline 1 & France & 1 & United Kingdom & 1 & USA & 1 & USA & 1 USA \\
\hline 2 & Germany & 2 & Germany & 2 & France & 2 & Germany & 2 Germany \\
\hline 3 & United Kingdom & 3 & France & 3 & United Kingdom & 3 & France & 3 United Kingdom \\
\hline 5 & Sweden & 6 & USA & 4 & Germany & 4 & United Kingdom & 4 France \\
\hline 13 & New Zealand & 10 & Sweden & 10 & Sweden & 10 & Sweden & 10 Sweden \\
\hline 14 & USA & 14 & Denmark & 14 & Denmark & 14 & Denmark & 14 New Zealand \\
\hline 15 & Denmark & 15 & New Zealand & 15 & New Zealand & 15 & New Zealand & 15 Denmark \\
\hline$x$ & Finland & 16 & Finland & 16 & Finland & 16 & Finland & 16 Finland \\
\hline
\end{tabular}

Table 1. Denmark's score on Anholt-GfK Roper Brands Index from 2007-2011

Source: Danish Government $(2011,10)$ 
The fact that the Danish brand failed to advance on the index did not present an immediate threat to the nation branding initiative or to the Task Force. On the contrary, this specific problem presented a solution for the bureaucrats. The very act of defining the consequences of the cartoon crisis as a reputational problem had positive reordering effects in terms of establishing "reputational problems" as the main driver of policy initiatives and bureaucratic expansion. Bureaucracies are problem-solving machines and therefore need problems to continue their existence. In this sense a reputation index that constantly produces new reputational risks was convenient for government bureaucrats.

Following this argument Denmark's position on the index did not make any difference at all. A low ranking would require initiatives in order to make advancements; a high ranking would require initiatives in order to consolidate the position achieved. And the recurring ratings and publication of the results served to maintain the organizational sensitivity towards reputational risk. In this sense the organizational sensitivity towards reputational risks became a generative strength of the Task Force.

\section{Bureaucracy is Caught in Successful Translation}

The Task Force did however face one major challenge. The final evaluation of the entire nation branding plan, and hence also of the Task Force, came closer. The bureaucrats found themselves in a position where they had no control over the outcome of this evaluation. The positive reordering effects of the Nation Brands Index had outweighed its incapacity for evaluating the work done by the Task Force. But contrary to the advantage of the ongoing production of reputational risks produced by the index, the lack of control was a problem that posed a real threat to the Task Force. Between 2009 and 2010 the bureaucrats therefore began advocating to the political leadership a shift to other evaluation tools. This advocacy occurred internally in the central government administration but also in annual reports where the Task Force accounted for their activities towards the public. One of the frequently used arguments put forward by the bureaucrats was that the objective was unrealistic. Here, Simon Anholt was enrolled as helper, as he had once deemed the goal of the Danish branding program "extremely ambitious" concluding that it would take an "extraordinary effort" (Danish Government 2010b, 4). The bureaucratic interpretation of this was that the administration should either have new "extraordinary" budgets or that the objective should be modified.

It was not easy to convince the political leadership. The bureaucrats found themselves caught in their own successful translation of the nation branding recipe. The Action Plan had made a convincing 


\section{Valuation Studies}

argument about the importance of measuring Denmark's reputation. Hence, it was difficult for the bureaucrats to find counterarguments without contradicting the original arguments that had enabled the very nation branding initiative. Although the politicians were reluctant to change a vital part of the plan that both parties (including the political coalition in parliament) had agreed upon, the internal struggle between bureaucrats and the political leadership came to an end when the Task Force presented an alternative measurement tool in the 2010 sequel to the Action Plan (Danish Government 2010a). This finally convinced the political leadership, perhaps also assisted by the fact that despite all efforts made Denmark had not improved its position on the index and there were no indications that the nation branding initiative would be able to meet the official objective and advance into the top ten.

Consequently, in 2011 the index was finally supplemented by a socalled "impact measurement method" (see Table 2); perhaps a pyrrhic victory, as this tool's methodology is even more opaque than that of the index. The impact measurement method was thus (optimistically) aiming at correlating government funding ("input") in branding related activities and projects with long-term effects on Danish GDP growth in exports and the attraction of tourism (Danish Government 2011). However, as the nation branding initiative was terminated in 2012 the Task Force never benefitted from this victory. Thus, in the final evaluation report made by an external consultancy the gap between the plan (policy formation) and practice (policy implementation) was subject to a harsh critique (Danish Government 2012).

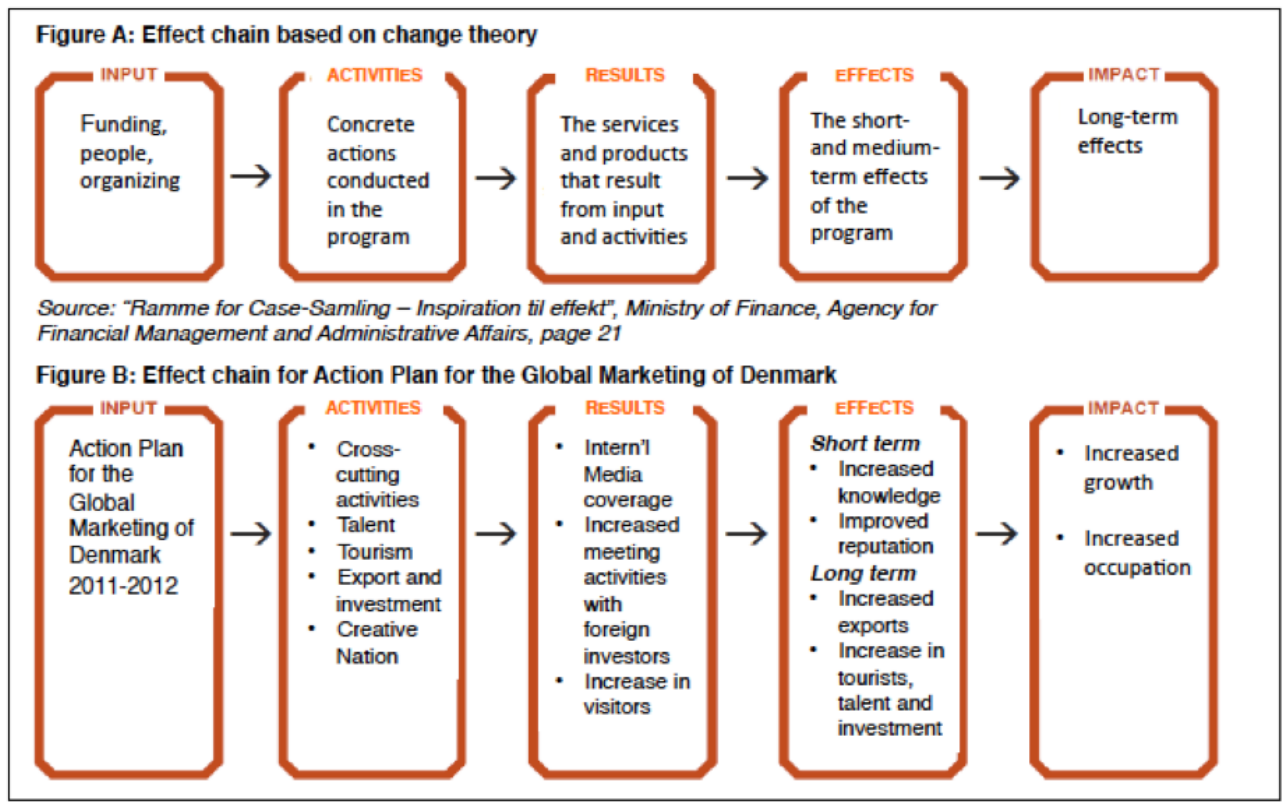

Table 2. The new "impact measurement method" devised in the last evaluation of the branding program (Danish Government, 2011, 11, our translation) 


\section{Conclusion: The Value of (e)Valuation}

The termination of the Danish nation brand initiative concurred with the critical conclusions of the final evaluation where the Task Force as a coordination and evaluation unit became itself the object of an external evaluation. By emphasizing the failure to align practical initiatives with the "programmatic text" of the project, the final evaluation indicates that the bureaucrats in the task force could have been more successful if they had abided by the nation branding logic in their practice and not only in their documents.

We contest this conclusion because it is based on the underlying assumption that valuation is a practice where values are stable entities and measurement is just a matter of accuracy. From our ANT vantage point, rather, the study shows that the Nation Brands Index as a measurement tool enacted its own object of measurement. That is, the index was an indispensable actor in establishing a nation branding actor network that successfully hosted a variety of policy initiatives from the Globalization Strategy. By establishing a consistent framework for measuring the reputational effects of these initiatives (although no one in the Task Force believed in this) the Nation Brands Index successfully translated these policy initiatives into nation branding projects. Hence, our argument is that it is a mistake to think of the Danish nation brand as a stable entity that existed prior to this enactment. The Danish nation brand-understood as a managerial object-came to exist because it was objectified through a series of translations. In this process the Anholt Nation Brands Index-from its initial inclusion of Denmark from 2006 onwards - served as a catalyst for this process whereby the nation brand gained status as a stable object. That is, it provided a means for addressing a wide range of policy initiatives and organizing them around a reputational nation branding logic.

This observation of our study does not contradict the literature that points to how various more or less stable perceptions and beliefs about nations have always existed (e.g. Anholt 2002; Olins 2002; Dinnie 2008). But we argue that these perceptions and beliefs have little resemblance to the multidimensional aggregates on which the conceptualization of nation brands is based. Perceptions exist in the minds of people whereas multidimensional nation branding aggregates are managerial objects that exist as a series of practices. Our study shows how the practice in the Task Force was affected by the contemporary conceptualization of nation branding-at least at document level. 


\section{Valuation Studies}

The nation brand gained status as a stable entity because the bureaucrats in central administration successfully translated the nation branding logic to fit their bureaucratic domain. This translation, however, came at a price. By accepting a measurement tool that was unable to measure the effects of their work, the Task Force lost control over its own future.

On the other hand, the index helped establish new organizational realities such as the Task Force and its further bureaucratic expansion. That is, the index became the driving force in creating new organizational realities as the brand was continuously enacted within this actor-network. This enactment at organization level is also visible at societal level in media discourse in Denmark from 2006 to 2014: a search in the Danish equivalent to LexisNexis shows that until 2006 only nine articles included terms such as "nation brand", "Danish brand" or "Denmark's brand." And only three of them addressed Denmark as a national brand while the others focused on country of origin. In 2014 the number had grown to almost 1000, demonstrating that the term has become widely used beyond the narrow domain of specialist language in the actor-network.

\section{References}

Anholt, Simon. 2002. "Foreword." Journal of Brand Management 9 (4): 229239.

- 2006. "Why Brand? Some Practical Considerations for Nation Branding." Place Branding and Public Diplomacy 2 (2): 97-107.

- 2007. Competitive Identity. The New Brand Management for Nations, Cities and Regions. New York, NY: Palgrave Macmillan.

Aronczyk, Melissa. 2008. "'Living the Brand': Nationality, Globality, and the Identity Strategies of Nation Branding Consultants." International Journal of Communication 2: 41-65.

- 2009. "How to Do Things with Brands: Uses of National Identity." Canadian Journal of Communication 34: 291-6.

Blichfeldt, Bodol Stilling. 2005. "Unmanageable Place Brands?" Place Branding 1 (4): 388-401.

Callon, Michel. 1986. "Some Elements of a Sociology of Translation: Domestication of the Scallops and the Fishermen of St Brieuc Bay." In Power, Action and Belief: A New Sociology of Knowledge, edited by John Law, 205-224. London: Routledge \& Kegan Paul.

Callon, Michel, and Bruno Latour. 1981. "Unscrewing the Big Leviathan: How Actors Macro-structure Reality and How Sociologists Help Them to Do So." In Advances in Social Theory and Methodology. Toward an Integration of Micro and Macro-sociologies, edited by Karin D. Knorr- 
Cetina and Aaron Victor Cicourel, 277-303. Boston, MA: Routledge \& Kegan Paul.

Christensen, Lars Thøger, Mette Morsing, and George Cheney. 2008. Corporate Communications: Convention, Complexity, and Critique. Los Angeles, CA: Sage Publications.

Danish Broadcasting Corporation. 2006. Former foreign minister EllemannJensen in the talkshow 'Debatten'. DR2. 16 February 2006.

Danish Government. 2006. Debatoplag: Danmarks omdømme [Discussion paper: Denmark's reputation]. Copenhagen: Ministry of Economic and Business Affairs.

—_. 2007. Action Plan for the Global Marketing of Denmark. Copenhagen: Ministry for Economic and Business Affairs.

- 2010a. Handlingsplan for offensiv global markedsforing af Danmark 2011-2012 [Action Plan for the Global Marketing of Denmark 20112012]. Copenhagen: Ministry of Economic and Business Affairs.

- 2010b. Status på implementering af handlingsplanen for Offensiv global markedsforing af Danmark 2009 [Progress report for the implementation of the Action Plan for the Global Marketing of Denmark]. Copenhagen: Ministry of Economic and Business Affairs.

2011. Action Plan for the Global Marketing of Denmark. Progress Report 2011. Copenhagen: Ministry for Economic and Business Affairs.

- - - 2012. Evaluering af Handlingsplanen for offensiv global markedsføring af Danmark 2007-2012 (Copenhagen Economics) [Final evaluation of Action Plan for the Global Marketing of Denmark 20072012). Copenhagen: Ministry of Economic and Business Affairs.

Dewey, John. 1939. Theory of Valuation. Chicago, IL: University of Chicago Press.

Dinnie, Keith. 2008. Nation Branding: Concepts, Issues, Practice (1st ed.). Oxford and Burlington, MA: Butterworth-Heinemann.

Dunleavy, Patrick, and Christopher Hood. 1994. "From Old Public Administration to New Public Management." Public Money and Management 14 (3): 9-16.

Fan, Ying. 2006. "Branding the Nation: What is Being Branded?" Journal of Vacation Marketing 12 (1): 5-14.

Fenton, Christopher, and Ann Langley. 2011. "Strategy as Practice and the Narrative Turn.” Organization Studies 32 (9): 1171-1196.

Frost, Randall. 2004. “Mapping a Country's Future.” BrandChannel June 2013. Available from http://www.brandchannel.com/features_effect. asp. Accessed June 2015.

Gertner, David. 2011. "Unfolding and Configuring Two Decades of Research and Publications on Place Marketing and Place Branding." Place Branding and Public Diplomacy 7 (2): 91-106.

Hacking, Ian. 1990. The taming of chance. Cambridge University Press.

Hansen, Hans Krause, and Mikkel Flyverbom. 2015. "The Politics of Transparency and the Calibration of Knowledge in the Digital Age." Organization 22 (6): 872-889. 


\section{Valuation Studies}

Helgesson, Claes-Fredrik, and Fabian Muniesa. 2013. "For What It's Worth: An Introduction to Valuation Studies." Valuation Studies 1(1): 1-10.

Helm, Sabrina. 2007. "One Reputation or Many? Comparing Stakeholders' Perceptions of Corporate Reputation." Corporate Communications: An International Journal 12 (3): 238-254.

Jansen, Sue Curry. 2008. Designer Nations: Neo-liberal Nation BrandingBrand Estonia. Social Identities 14 (1): 121-142.

Kaneva, Nadia. 2011. "Nation Branding: Toward an Agenda for Critical Research." International Journal of Communication 5: 117-141.

—. 2012. "Nation Branding in Post-Communist Europe: Identities, Markets, and Democracy." In Branding post-communist nations: Marketizing national identities in the "new" Europe, edited by Nadia Kaneva, 3-22. Routledge, 2011.

Kaneva, Nadia, and Delia Popescu. 2011. "National Identity Lite." International Journal of Cultural Studies 14 (2): 191-207.

Kavaratzis, Mihalis. 2009. "Cities and their brands: Lessons from corporate branding." Place Branding and Public Diplomacy 5 (1): 26-37.

Kavaratzis, Mihalis, and Mary Jo Hatch. 2013. "The Dynamics of Place Brands: An Identity-based Approach to Place Branding Theory." Marketing Theory 13 (1): 69-86.

Kjellberg, Hans, Alexandre Mallard, Diane-Laure Arjaliès, Patrik Aspers, Stefan Beljean, Alexandra Bidet, Alberto Corsin, Emmanuel Didier, Marion Fourcade, Susi Geiger, Klaus Hoeyer, Michèle Lamont, Donald MacKenzie, Bill Maurer, Jan Mouritsen, Ebba Sjögren, Kjell Tryggestad, François Vatin, and Steve Woolgar. 2013. "Valuation Studies? Our Collective Two Cents." Valuation Studies 1 (1): 11-30.

Klein, Naomi. 2000. No Logo: Taking Aim at the Brand Bullies (1st Picador USA ed.). New York, NY: Picador.

Lamont, Michèle. 2012. "Toward a comparative sociology of valuation and evaluation.” Sociology 38 (1): 201-221.

Latour, Bruno. 1986. "The Powers of Association." In Power, Action and Belief. A New Sociology of Knowledge?, edited by John Law, pp. 264280. London: Routledge \& Kegan Paul.

-1999. Pandora's Hope: Essays on the Reality of Science Studies. Cambridge, MA: Harvard University Press.

Ministry of Foreign Affairs of Denmark. 2006. Challenges of Globalisation. Opening Remarks by the Danish Minister for Foreign Affairs Dr. Per Stig Møller First Meeting of the Advisory Board on Globalisation. Copenhagen 31 March 2006.

- 2009. Denmark in dialogue with the world: Danish public diplomacy in practice [Danmark i dialog med verden-eksempler på dansk public diplomacy i praksis]. Public Diplomacy and Communication, pp. 1-33.

Olins, Wally. 2002. "Branding the Nation-The Historical Context." Brand Management 9 (4-5): 241-248. 
Pamment, James. 2014. "Articulating Influence: Toward a Research Agenda for Interpreting the Evaluation of Soft Power, Public Diplomacy and Nation Brands." Public Relations Review 40: 50-59.

Porter, Theodore M. 1995. Trust in Numbers: The Pursuit of Objectivity in Science and Public Life. Princeton, NJ: Princeton University Press.

Rasmussen, Rasmus Kjærgaard. 2014. Nation Branding in Practice. An Analysis of the Danish Government Administration's Interpretation and Organization of the "Action Plan for the Global Marketing of Denmark 2007-2010.” PhD Thesis, University of Southern Denmark, Department of Language and Communication, Odense.

- Forthcoming. "Re-thinking counter narratives in organizational analysis: master narratives-as-authoritative texts." In Counter-narratives in and around Organizations, edited by Timothy Kuhn, Sanne Frandsen, and Marianne Lumholt. London: Routledge.

Rasmussen, Rasmus Kjærgaard, and Henrik Merkelsen. 2012. "The New PR of States: How Nation Branding Practices Affect the Security Function of Public Diplomacy.” Public Relations Review 38 (5): 810-818.

- 2014. "The Risks of Nation Branding as Crisis Response: A Case Study of How the Danish Government Turned the Cartoon Crisis into a Struggle with Globalization.” Place Branding and Public Diplomacy 10 (3): 230-248.

Ren, Carina, and Can-Seng Ooi. 2013. "Auto-communicating MicroOrientalism: Articulating 'Denmark' in China at the Shanghai Expo." Asia Europe Journal 11 (2): 129-45.

Ren, Carina, and Szilvia Gyimóthy. 2013. Transforming and Contesting Nation Branding Strategies: Denmark at the Expo 2010. Place Branding and Public Diplomacy 9 (1): 17-29.

Shore, Cris, and Susan Wright. 1997. "Policy. A New Field of Anthropology." In Anthropology of Policy. Critical Perspectives on Governance and Power, edited by Cris Shore and Susan Wright, 1. London: Routledge.

Special report. 2006. Denmark's International Image Q1 2006. The Anholt Nation Brands Index. Simon Anholt and GMI, Inc.

Stöber, Birgit. 2008. "Place Branding-How the Private Creates the Public." In Critical Perspectives on Private Authority in Global Politics, edited by Hans Krause Hansen and Dorte Salskov-Iversen, pp. 169-187. Basingstoke: Palgrave Macmillan.

Szondi, Gyorgy. 2010. "From Image Management to Relationship Building: A Public Relations Approach to Nation Branding." Place Brand Public Diplomacy 6 (4): 333-343.

TimesOnline. 2006. "70,000 gather for violent Pakistan cartoons protest.” 15 February. Retrieved from http://www.timesonline.co.uk/tol/news/world/ asia/article731005.ece, accessed October 2012.

Vatin, François. 2013. "Valuation as Evaluating and Valorizing." Valuation Studies 1 (1): 31-50.

Wartick, Steven L. 2002. "Measuring Corporate Reputation: Definition and Data.” Business \& Society 41 (4): 371-392.

Widler, Janine. 2007. "Nation Branding: With Pride against Prejudice.” Place Branding and Public Diplomacy 3 (2): 144-150. 


\section{Valuation Studies}

Henrik Merkelsen received his $\mathrm{PhD}$ in risk management from Copenhagen Business School. He is Associate Professor at the Department of Strategic Communication, Lund University. His doctoral work was on risk management in the food industry. Apart from his academic work, he has worked as a public relations advisor for 15 years. He is frequently used as commentator in Danish media and as speaker at seminars for business leaders and public relations professionals. His current research is centered on risk management and public relations and his papers have been published in leading journals such as Risk Analysis, Journal of Risk Research and Public Relations Review.

Rasmus Kjærgaard Rasmussen received his $\mathrm{PhD}$ in organizational communication from the University of Southern Denmark. He is Assistant Professor at the Department of Communication, Business and Information Technologies, Roskilde University. His doctoral thesis was an analysis of the complexities surrounding the Danish government administration's implementation of a nation branding programme from 2006 to 2012 . He has published on nation branding and public diplomacy, as well as on other forms of PR and strategic communication. His latest research has appeared in Public Relations Review and Place Branding and Public Diplomacy. 